\title{
Hubungan Kepemimpinan Visioner Kepala Sekolah dan Kinerja Guru dengan Keefektifan Sekolah Dasar Negeri
}

\author{
Faizah Nur Amalia, Maisyaroh, R. Bambang Sumarsono \\ Universitas Negeri Malang, Jl. Semarang No. 5 Malang, Jawa Timur, Indonesia \\ *Penulis korespondensi, Surel: faizah.nuramalia08@gmail.com
}

Paper received: 25-8-2021; revised: 8-9-2021; accepted: 15-9-2021

\begin{abstract}
The aim of this study is to describe visionary leadership, teacher's performance, school effectiveness, visionary principals' leadership relationships and school effectiveness, relationship between teacher's performance and school effectiveness, and the principal's visionary leadership relationship and teacher's performance with school effectiveness. This study uses a quantitative approach, with a correlation research design. Sampling uses proportional sampling and area (cluster) sampling techniques with the acquisition of 86 teachers as respondents. The technique of collecting data uses a closed questionnaire. Analysis of the data used is descriptive analysis, and hypothesis testing using Pearson Product Moment correlation analysis and multiple correlation. The results obtained by the principal's visionary leadership, teacher's performance, and school effectiveness in the medium category, there is a relationship between visionary leadership and school effectiveness, there is a relationship between teacher performance and school effectiveness, there is a relationship between visionary leadership and teacher performance with school effectiveness at SDN Lawang, Malang.
\end{abstract}

Keywords: visionary leadership; teacher's performance; school effectiveness

\begin{abstract}
Abstrak
Tujuan penelitian ini untuk mendeskripsikan kepemimpinan visioner, kinerja guru, tingkat keefektifan sekolah, hubungan kepemimpinan visioner kepala sekolah dan keefektifan sekolah, hubungan kinerja guru dan keefektifan sekolah, serta hubungan kepemimpinan visioner kepala sekolah dan kinerja guru dengan keefektifan sekolah. Penelitian ini menggunakan pendekatan kuantitatif, dengan rancangan penelitian korelasi. Pengambilan sampel menggunakan teknik proporsional sampling dan teknik area (cluster) sampling dengan perolehan 86 guru sebagai responden. Teknik pengumpulan data menggunakan angket tertutup. Analisis data yang digunakan yaitu analisis deskriptif, dan uji hipotesis menggunakan analisis korelasi Pearson Product Moment dan korelasi berganda. Hasil penelitian diperoleh kepemimpinan visioner kepala sekolah, kinerja guru, dan keefektifan sekolah dalam kategori sedang, terdapat hubungan antara kepemimpinan visioner dan keefektifan sekolah, terdapat hubungan antara kinerja guru dan keefektifan sekolah, terdapat hubungan antara kepemimpinan visioner dan kinerja guru dengan keefektifan sekolah di SDN Kecamatan Lawang, Kabupaten Malang.
\end{abstract}

Kata kunci: kepemimpinan visioner; kinerja guru; keefektifan sekolah

\section{Pendahuluan}

Keefektifan merupakan suatu yang dijadikan ukuran sejauh mana tujuan/sasaran (kualitas, kuantitas, dan waktu) dalam mencapai tujuan yang telah ditetapkan. Sekolah efektif yaitu sekolah yang menunjukkan keselarasan antara hasil yang dicapai dengan hasil yang diharapkan (objective, targets, intended outputs) sebagaimana yang telah dicapai. Keefektifan sekolah menurut Taylor (1990) dalam Komariah dan Triatna (2004) yaitu suatu ukuran keberhasilan sekolah dalam mengelola seluruh sumber daya sekolah untuk mencapai tujuan yang selaras dengan visi dan misi sekolah yang telah ditetapkan. Mencapai keefektifan sekolah 
tentunya perlu adanya dukungan, kerja sama dan komitmen dari seluruh warga sekolah mulai dari kepada sekolah, guru, staf/pegawai, siswa, orangtua siswa, dan masyarakat.

Undang-Undang Nomor 20 Tahun 2003 tentang Sistem Pendidikan Nasional Bab XI Pasal 39 dinyatakan bahwa pendidik merupakan tenaga profesional yang bertugas merencanakan dan melaksanakan proses pembelajaran, serta melakukan bimbingan dan pelatihan. Sementara itu, Undang-Undang Nomor 14 Tahun 2005 Pasal 4 mengenai Guru dan Dosen dinyatakan bahwa guru sebagai tenaga profesional mempunyai fungsi meningkatkan martabat dan peran guru sebagai agen pembelajaran guna dalam rangka meningkatkan mutu pendidikan nasional. Mutu suatu lembaga pendidikan sangat ditentukan oleh pemimpin dan para guru dalam mengelola lembaga pendidikan tersebut secara profesional dan komitmen bersama.

Menciptakan kinerja guru di sekolah yang baik, tentunya dipengaruhi oleh pengetahuan, sikap, dan motivasi. Hal tersebut diperkuat dengan hasil wawancara peneliti dengan Kepala SDN Bedali 02 yaitu Ibu Setyowati pada Tanggal 10 Januari 2018. Beliau memaparkan bahwa salah satu faktor yang mempengaruhi kinerja guru di sekolah yaitu motivasi yang diberikan oleh kepala sekolah kepada guru. Jenis motivasi kepala sekolah kepada guru ini juga dipengaruhi jenis kepemimpinan yang diterapkan oleh kepala sekolah karena hal ini mempengaruhi komunikasi atau hubungan antara kepala sekolah dan guru. Komunikasi yang baik antara kepala sekolah dengan guru dapat membantu mengatasi permasalahan guru dan memberikan motivasi pada proses kerja guru untuk menghasilkan kinerja yang memuaskan.

Sekolah yang efektif mengeksplisitkan kepemimpinan sebagai ciri penting keefektifan sekolah. Keberadaan pemimpin haruslah dapat menjalankan tugas dan fungsinya dalam menghadapi perubahan yang terjadi di sekolah, mendayagunakan seluruh sumber daya yang ada dengan pendekatan partisipatif, dan didasarkan atas kemampuan profesional yang menjadi indikator kepemimpinan efektif. Kepemimpinan efektif seyogyanya bertipe pemimpin yang visioner, dengan menetapkan tujuan masa depan sekolah yang profesional. Di mana visi dan misi sekolah yang dirumuskan oleh kepala sekolah digunakan sebagai antisipasi dan proyeksi kebutuhan di masa depan yang tidak menentu.

Visionary leadership merupakan suatu kemampuan seseorang untuk menciptakan, merumuskan, mensosialisasikan/ mengkomunikasikan/ mentransformasikan, serta mengimplementasikan pemikiran hasil pemikiran ideal yang diperoleh dari pemikiran diri sendiri atau hasil pemikiran bersama dalam suatu kelompok yang diyakini sebagai cita-cita organisasi di masa depan (Komariah dan Triatna, 2004). Kepemimpinan visioner merupakan pola kepemimpinan yang ditunjukkan untuk memberi arti pada kerja dan usaha yang perlu dilakukan bersama-sama oleh para anggota organisasi dengan memberi arahan dan makna pada kerja untuk mencapai tujuan berdasarkan visi yang jelas (Kartanegara, 2013). Jadi dapat disimpulkan kepemimpinan visioner (visionary leadership) adalah kemampuan pemimpin yang berorientasi pada masa depan serta dapat merumuskan, mentransformasikan, serta mengkomunikasikan visi, misi, tujuan organisasi yang diperoleh dari hasil pemikiran pemimpin atau dengan bersama anggota kelompok yang diyakini sebagai visi, misi, dan tujuan organisasi di masa depan.

Pemimpin yang visioner ini juga diperkuat dengan adanya Peraturan Menteri Nomor 19 Tahun 2007 tentang Standar Pengelolaan Pendidikan oleh Satuan Pendidikan Dasar dan Menengah yang berisi mengenai peraturan akan dibuatnya perencanaan program pendidikan 
pada satuan pendidikan. Peraturan ini menjelaskan bahwa setiap satuan pendidikan atau sekolah harus memiliki visi, misi dan tujuan sekolah dan dapat ditinjau serta dirumuskan kembali secara berkala yang disesuaikan dengan perkembangan dan tantangan masyarakat. Adanya peraturan ini semakin memperkuat pentingnya kepemimpinan visioner oleh kepala sekolah dalam mengelola pendidikan di sekolah.

Kepemimpinan yang visioner menurut Nanus (2001) dalam Komariah dan Triatna (2004) harus berpedoman pada empat pilar yaitu: (1) penentu arah, (2) agen perubahan, (3) juru bicara, (4) dan pelatih. Kepemimpinan di lembaga pendidikan yang menerapkan kepemimpinan visioner ini pemimpin mampu memprediksi kebutuhan dan kondisi di masa depan pendidikan dan berupaya untuk mencapai tujuan jangka panjang tersebut. Hasil yang tampak apabila pemimpin menerapkan kepemimpinan visioner yaitu ketika cara pemimpin dalam menentukan kebijakan, dan keputusan sebagai dasar pertimbangan pengambilan suatu keputusan yang ditetapkan berdasarkan kebutuhan sekolah. hal ini juga dipertegas oleh penelitian Kantabutra (2003) definisi operasional, konten visi yang diusulkan untuk pemeriksaan di sekolah umum dioperasionalkan sebagai: (a) kepuasan siswa citra adalah sejauh mana pernyataan visi mengacu pada peningkatan kepuasan siswa, (b) citra kepuasan guru adalah sejauh mana pernyataan visi berisi referensi untuk meningkatkan kepuasan guru; dan (c) citra efisiensi adalah sejauh mana pernyataan visi berisi referensi untuk meningkatkan efisiensi sekolah. sedangkan penelitian Kantabutra (2005) memperoleh hasil bahwa kepemimpinan visioner yang didukung oleh penelitian masa depan, model yang diusulkan akan memiliki implikasi praktis yang signifikan, terutama untuk reformasi sekolah publik. Setelah komponen visi yang efektif untuk sekolah umum diketahui, prakata sekolah publik dapat menerapkannya untuk mengembangkan visi mereka dalam memaksimalkan kinerja sekolah melalui kepuasan guru dan siswa, prestasi siswa, dan efisiensi. Model ini menunjukkan bahwa visi yang singkat, jelas, abstrak, menantang, berorientasi masa depan, stabil, dan diinginkan, dan mereka yang mengandung tingkat guru yang tinggi dan kepuasan siswa, dan gambaran efisiensi, akan lebih efektif dalam meningkatkan kepuasan guru dan siswa, prestasi siswa, dan efisiensi. Kepala sekolah tidak hanya berusaha mengembangkan visi sesuai karakteristik di atas, tetapi juga disarankan untuk memperhatikan tiga faktor realisasi visi Kepala Sekolah, Guru dan Faktor Organisasi.

Peneliti mengambil lokasi penelitian di Kecamatan Lawang yang berada di Kabupaten Malang, Jawa Timur. Di Kecamatan Lawang terdiri dari 52 Sekolah terdiri dari 46 SDN dan 6 SD Swasta, 426 guru dan 1.623 siswa. Alasan peneliti mengambil SD Negeri sebagai populasi penelitian karena jumlah SD Negeri lebih dominan dibanding dengan jumlah SD Swasta di Kecamatan Lawang, Kabupaten Malang. Hasil wawancara dengan Koordinator Pengawas Tingkat Sekolah Dasar (SD) Kabupaten Malang, yaitu Bapak Nawaji, pada Tanggal 12 Januari 2018. Beliau memaparkan bahwa tingkat pendidikan di Kecamatan Lawang sudah tergolong baik dibanding kecamatan lain di Kabupaten Malang. Kecamatan Lawang dijadikan sebagai barometer pendidikan di Kabupaten Malang, khususnya pada bidang akademik dan non akademik. Kecamatan Lawang selalu berada pada peringkat sepuluh besar Nilai Ujian Nasional (NUN) dan selalu aktif dalam perlombaan Akademik dan Non Akademik di Kabupaten Malang. Peringkat sepuluh besar ini tergolong baik, karena hal ini juga mempertimbangkan dengan jumlah 52 sekolah dasar negeri dan swasta dan jumlah siswa 1.623. Berdasarkan data dan hasil wawancara tersebut dijadikan peneliti sebagai alasan mengambil lokasi penelitian di Kecamatan Lawang. 
Hasil penelitian terdahulu sebagaimana diungkap oleh Widyawati (2015) bahwa tingkat kepemimpinan visioner kepala sekolah di SMPN se-Kota Malang kategori sangat baik, tingkat kinerja tenaga pendidikan di SMPN se-Kota Malang kategori sangat baik, kualitas sekolah di SMPN se-Kota Malang termasuk kategori baik, terdapat hubungan yang signifikan antara kepemimpinan visioner kepala sekolah dan tingkat kinerja tenaga pendidikan terhadap kualitas sekolah di SMPN se-Kota Malang. Penelitian kedua, oleh Supardi (2014) memperoleh kesimpulan bahwa terdapat pengaruh positif dan signifikan kepemimpinan visioner kepala raudhatul athfal dan budaya organisasi terhadap disiplin kerja guru. Penelitian ketiga, oleh Irwana (2015) memperoleh kesimpulan bahwa kepemimpinan visioner kepala sekolah berada pada kategori tinggi, Kinerja guru berada pada kategori tinggi, dan efektivitas sekolah berada pada kategori sangat tinggi. Kepemimpinan visioner kepala sekolah dan kinerja guru memberikan pengaruh yang signifikan sedang terhadap efektivitas sekolah.

Pembaharuan dalam penelitian yang peneliti lakukan ini terletak pada variabel kinerja guru dalam lingkup kinerja guru kelas dan guru mata pelajaran berstatus Pegawai Negeri Sipil (PNS) dan Guru Tidak Tetap (GTT) serta pada variabel keefektifan sekolah yang ditinjau dari kurikulum, lingkungan belajar, ramah siswa, manajemen sekolah, berorientasi pada prestasi, pelibatan orangtua dan masyarakat. Berdasarkan hasil penelitian terdahulu dan studi pendahuluan melalui wawancara dengan kepala sekolah dan pengawas SDN yang ada di Kecamatan Lawang, Kabupaten Malang dan diperkuat dengan undang-undang atau peraturan, maka peneliti melakukan penelitian dengan Judul "Hubungan Kepemimpinan Visioner Kepala Sekolah dan Kinerja Guru dengan Keefektifan Sekolah Dasar Negeri di Kecamatan Lawang, Kabupaten Malang".

\section{Metode}

Penelitian ini menggunakan pendekatan kuantitatif, dengan rancangan penelitian korelasi. Variabel dalam penelitian ini yaitu variabel bebas terdiri dari variabel kepemimpinan visioner kepala sekolah $\left(\mathrm{X}_{1}\right)$ dan variabel kinerja guru $\left(\mathrm{X}_{2}\right)$, serta variabel terikat yaitu keefektifan sekolah (Y). Populasi dalam penelitian ini menggunakan Sekolah Dasar Negeri (SDN) se-Kecamatan Lawang, Kabupaten Malang sejumlah 46 SDN dengan 426 orang guru yang tersebar dalam sembilan gugus sekolah. Teknik pengambilan sampel yang digunakan yaitu teknik proporsional sampling dan teknik area (cluster) sampling sehingga memperoleh hasil yaitu 86 guru sebagai responden. Penelitian ini menggunakan seluruh guru kelas dan guru mata pelajaran berstatus PNS dan GTT sebagai unit analysis. Penelitian ini, dengan sengaja kepala sekolah tidak ikutkan dalam pengisian kuesioner (angket). Karena unit analisis guru kelas dan guru mata pelajaran, maka dalam penelitian ini mengukur tingkat kepemimpinan visioner dan keefektifan sekolah berdasarkan penilaian atau persepsi dari guru di sekolah.

Teknik pengumpulan data yang digunakan dalam penelitian ini yaitu menggunakan teknik kuesioner (angket), teknik wawancara, dan teknik dokumentasi. Teknik utama yang digunakan dalam pengumpulan data yaitu teknik kuesioner (angket), dan untuk penguatan data penelitian ini, juga melakukan teknik wawancara dan teknik dokumentasi. Teknik kuesioner (angket) tertutup. Alasan menggunakan angket tertutup dipertegas dengan pernyataan Umar (2003: 82) menyatakan bahwa kuesioner (angket) bersifat tertutup hanya dengan memberikan tanda cek list (P) pada jawaban yang benar. Peneliti dalam penelitian ini memodifikasi alternatif jawaban menggunakan empat (4) alternatif jawaban, dikarenakan peneliti ingin menghindari jawaban ragu-ragu atau jawaban tengah pada penelitian ini. 
Analisis data yang digunakan yaitu analisis deskriptif, dan uji hipotesis menggunakan analisis korelasi Pearson Product Moment dan korelasi berganda. Perhitungan analisis dalam penelitian ini menggunakan Software Statistical Product and Service Solution (SPSS) 24 for window. Teknik deskriptif ini digunakan untuk mendeskripsikan variabel kepemimpinan visioner kepala sekolah, kinerja guru, dan keefektifan sekolah di SDN Kecamatan Lawang, Kabupaten Malang. Analisis korelasi Pearson Product Moment digunakan untuk mengetahui hubungan antara kepemimpinan visioner dan keefektifan sekolah serta mengetahui hubungan kinerja guru dan keefektifan sekolah. Sedangkan analisis korelasi berganda digunakan untuk mengetahui hubungan kepemimpinan visioner dan kinerja guru dengan keefektifan sekolah di SDN Kecamatan Lawang, Kabupaten Malang.

\section{Hasil dan Pembahasan}

\subsection{Hasil}

\subsubsection{Tingkat Kepemimpinan Visioner}

Variabel kepemimpinan visioner $\left(\mathrm{X}_{1}\right)$ diperoleh nilai mean sebesar 87,91 dan standar deviasi sebesar 6,86. Setelah mengetahui perolehan besar nilai mean dan nilai standar deviasi, kemudian mencari rentang nilai kelas interval untuk mengetahui tingkat kepemimpinan visioner. Hasil perhitungan analisis deskriptif yang diambil dari 86 sampel responden yaitu 5 responden menyatakan tingkat kepemimpinan visioner kepala sekolah berada dalam kategori sangat tinggi, 24 responden menyatakan tingkat visioner berada dalam kategori tinggi, 25 responden menyatakan tingkat kepemimpinan visioner berada dalam kategori sedang, 28 responden menyatakan tingkat kepemimpinan visioner berada dalam kategori rendah, dan 4 responden menyatakan tingkat kepemimpinan visioner berada dalam kategori sangat rendah. Nilai mean yang diperoleh variabel kepemimpinan visioner sebesar 87,91, berada pada interval 84,49 - 91,34. Sehingga dari hasil tersebut memperoleh simpulan tingkat kepemimpinan visioner kepala sekolah menurut persepsi guru di SDN Kecamatan Lawang, Kabupaten Malang berada dalam kategori sedang.

\subsubsection{Kinerja Guru}

Variabel kinerja guru $\left(\mathrm{X}_{2}\right)$ diperoleh nilai mean sebesar 75,84 dan standar deviasi sebesar 8,84. Setelah mengetahui perolehan besar nilai mean dan nilai standar deviasi, kemudian mencari rentang nilai kelas interval untuk mengetahui tingkat kinerja guru. Berdasarkan perhitungan analisis deskriptif yang diambil dari 86 sampel responden yaitu 4 responden menyatakan tingkat kinerja guru berada dalam kategori sangat tinggi, 24 responden menyatakan tingkat kinerja guru berada dalam kategori tinggi, 25 responden menyatakan tingkat kinerja guru berada dalam kategori sedang, 27 responden menyatakan tingkat kinerja guru berada dalam kategori rendah, dan 4 responden menyatakan tingkat kinerja guru berada dalam kategori sangat rendah. Nilai mean yang diperoleh variabel kinerja guru sebesar 75,84, berada pada interval 71,43 - 80,26. Sehingga disimpulkan bahwa tingkat kinerja guru di SDN Kecamatan Lawang, Kabupaten Malang dalam kategori sedang. 


\subsubsection{Keefektifan Sekolah}

Variabel keefektifan sekolah (Y) memperoleh nilai mean sebesar 157,29 dan standar deviasi sebesar 12,87. Setelah mengetahui perolehan besar nilai mean dan nilai standar deviasi, kemudian mencari rentang nilai kelas interval untuk mengetahui tingkat keefektifan sekolah. Berdasarkan hasil perhitungan analisis deskriptif yang diambil dari 86 sampel responden yaitu 1 responden menyatakan tingkat keefektifan sekolah berada dalam kategori sangat tinggi, 29 responden menyatakan tingkat keefektifan sekolah berada dalam kategori tinggi, 33 responden menyatakan tingkat keefektifan sekolah berada dalam kategori sedang, 14 responden menyatakan tingkat keefektifan sekolah berada dalam kategori rendah, dan 9 responden menyatakan tingkat keefektifan sekolah berada dalam kategori sangat rendah. Nilai mean yang diperoleh variabel keefektifan sekolah sebesar 141,86, berada pada interval 150,86 - 163,72. Sehingga disimpulkan bahwa tingkat keefektifan sekolah menurut persepsi guru di SDN Kecamatan Lawang, Kabupaten Malang dalam kategori sedang.

\subsubsection{Hubungan Kepemimpinan Visioner dan Keefektifan Sekolah}

Hubungan kepemimpinan visioner $\left(\mathrm{X}_{1}\right)$ dan keefektifan sekolah $(\mathrm{Y})$ dalam penelitian ini dihitung menggunakan Analisis korelasi Pearson Product Moment (2 tailed) dengan signifikansi sebesar 5\% (0,050). Dalam penelitian ini menggunakan 86 sampel responden guru SDN di Kecamatan Lawang, Kabupaten Malang. Hasil perhitungan analisis korelasi, diperoleh hasil koefisien korelasi sebesar 0,539 dan hasil signifikansi sebesar 0,000 $<0,050$. Sehingga menghasilkan hipotesis penelitian yaitu $\mathrm{H}_{0}$ ditolak dan $\mathrm{H}_{1}$ diterima. Jadi kesimpulannya secara parsial terdapat hubungan signifikan antara variabel kepemimpinan visioner $\left(\mathrm{X}_{1}\right)$ dan keefektifan sekolah (Y).

\subsubsection{Hubungan Kinerja Guru dan Keefektifan Sekolah}

Hasil perhitungan analisis korelasi Pearson Product Moment (2 tailed) dengan signifikansi sebesar 5\% (0,050), diperoleh hasil koefisien korelasi sebesar 0,461 dan signifikansi sebesar $0,000<0,050$. Sehingga menghasilkan hipotesis penelitian yaitu $\mathrm{H}_{0}$ ditolak dan $\mathrm{H}_{1}$ diterima. Jadi kesimpulannya yaitu secara parsial terdapat hubungan signifikan antara variabel kinerja guru $\left(\mathrm{X}_{2}\right)$ dan keefektifan sekolah $(\mathrm{Y})$.

\subsubsection{Hubungan Kepemimpinan Visioner dan Kinerja Guru dengan Keefektifan Sekolah}

Perhitungan uji hipotesis yang digunakan untuk mengetahui hubungan antara kepemimpinan visioner $\left(\mathrm{X}_{1}\right)$ dan kinerja guru $\left(\mathrm{X}_{2}\right)$ dengan keefektifan sekolah $(\mathrm{Y})$ yaitu menggunakan analisis korelasi berganda dengan signifikansi sebesar 5\% (0,050). Hasil perhitungan analisis korelasi berganda, bahwa besarnya hubungan kepemimpinan visioner dan kinerja guru dengan keefektifan sekolah diperoleh koefisien sebesar 0,585. Sedangkan hasil signifikansi sebesar $0,000<0,050$. Sehingga menghasilkan hipotesis penelitian yaitu $\mathrm{H}_{0}$ ditolak dan $\mathrm{H}_{1}$ diterima. Jadi kesimpulannya yaitu secara simultan terdapat hubungan signifikan antara kepemimpinan visioner $\left(\mathrm{X}_{1}\right)$ dan variabel kinerja guru $\left(\mathrm{X}_{2}\right)$ dengan keefektifan sekolah (Y). 


\subsection{Pembahasan}

\subsubsection{Kepemimpinan Visioner}

Hasil penelitian variabel kepemimpinan visioner $\left(\mathrm{X}_{1}\right)$ yang diisi oleh 86 guru sebagai responden diperoleh nilai mean variabel kepemimpinan visioner sebesar 87,91, berada pada interval 84,49 - 91,34. Sehingga tingkat kepemimpinan visioner kepala sekolah menurut persepsi guru di SDN Kecamatan Lawang, Kabupaten Malang berada dalam kategori sedang.

Dilihat dari tingkat kepemimpinan visioner yang mencapai rata-rata (mean) 87.91 dapat dikatakan bahwa kepala sekolah di SDN se Kecamatan hampir semua telah mempunyai dan menerapkan karakteristik yang ada pada pemimpin yang visioner. Karakteristik kepemimpinan visioner dalam penelitian ini kepala sekolah sebagai: penentu arah, agen perubahan, juru bicara, pelatih, penciptaan visi, perumusan visi, transformasi visi, implementasi visi, mengembangkan program, mendelegasikan program, konsultan guru, berupaya peningkatan kemampuan guru, dan pengambil keputusan.

Berdasarkan hasil data kepemimpinan visioner $\left(\mathrm{X}_{1}\right)$ yang dipersepsi oleh guru menyatakan bahwa kepala sekolah di SDN di Kecamatan Lawang, Kabupaten Malang telah menerapkan kepemimpinan visioner dalam proses pendidikan sesuai dengan teori dan konsep kepemimpinan visioner yang berorientasi pada masa depan. Diperkuat dengan adanya konsep persepsi menurut Rakhmat, (2011) merupakan kemampuan seseorang tentang objek, peristiwa, atau hubungan-hubungan yang diperoleh dengan menyimpulkan informasi dan menafsirkan pesan tersebut. Persepsi guru dalam memberikan penilaian terhadap kepemimpinan visioner yang dimiliki kepala sekolah yang dilihat berdasarkan kepribadian kepada sekolah dalam pengambilan keputusan, sikap dan kemampuan kepada sekolah dalam membuat, mengembangkan, mendelegasikan dan melaksanakan program/kegiatan sekolah berdasarkan visi dan misi yang telah dimiliki serta berorientasi pada kesuksesan di masa depan.

Kemampuan kepemimpinan visioner kepala sekolah dalam penelitian ini yaitu kemampuan kepala sekolah di SDN Kecamatan Lawang dalam menciptakan perencanaan di masa depan (jangka menengah/jangka panjang) yang berkomitmen pada visi dan misi yang telah dibuat oleh kepada sekolah, sehingga program/kegiatan serta kebijakan yang dibuat kepala sekolah merujuk dari visi dan misi tersebut. Hal ini diperkuat dengan adanya teori kepemimpinan visioner yaitu suatu kemampuan seorang pemimpin dalam menyusun/ merumuskan, mengkomunikasikan/ mentransformasikan, dan mengimplementasikan hasil pemikiran ideal yang bersumber dari diri sendiri ataupun hasil interaksi sosial antara anggota organisasi ataupun stakeholders yang dapat digunakan sebagai cita-cita organisasi di masa depan yang harus dicapai dengan komitmen bersama dalam organisasi. Konsep kepemimpinan visioner menurut Nanus (2001) dalam Komariah dan Triatna (2004) tentang empat pilar kepemimpinan visioner yaitu (1) penentu arah, tampil sebagai pelopor yang dapat menentukan arah dan tujuan melalui pikiran cerdas, rasional dan tindakan yang nyata; (2) agen perubahan, melakukan gebrakan baru melalui program/kegiatan, agenda terbaru secara jelas dan rasional yang dapat memicu kinerja dan menerima tantangan baru demi kemajuan sekolah; (3) juru bicara, kemampuan dalam berkomunikasi untuk menyampaikan pemikiran, gagasan, dan tulisan sehingga mampu membangun komitmen dan menyampaikan berbagai 
kepentingan kepada stakeholders; (4) pelatih, memberikan contoh, teladan, atau cara kerja dalam mengimplementasikan visi.

\subsubsection{Kinerja Guru}

Hasil penelitian menunjukan kinerja guru di SDN se Kecamatan Lawang, Kabupaten Malang dalam kategori sedang yaitu peroleh mean sebesar 75,84 pada rentang interval 71,43 - 80,26. Hal ini menunjukan bahwa guru-guru telah berupaya melakukan tugas dan kewajibannya melalui perencanaan pembelajaran, pelaksanaan pembelajaran, membimbing guru, membimbing siswa, serta melaksanakan pengembangan diri. Guru merupakan sentral yang dapat membawa perubahan dalam mencapai keberhasilan peserta didik di sekolah karena guru yang terlibat secara aktif dan langsung kepada peserta didik. Tanpa adanya guru yang mempunyai kinerja baik maka sedikit kemungkinan sekolah dapat mencapai tujuan pendidikan.

Pengembangan butir pernyataan pada variabel kinerja guru dalam penelitian ini merujuk dan memodifikasi variabel kinerja guru dari Permen PAN \& RB Nomor 16 Tahun 2009 dan Castetter dalam Wahab dan Umiarso (2010). Penilaian kinerja guru berdasarkan Peraturan Menteri Negara Pendayagunaan Aparatur Negara dan Reformasi Birokrasi (Permen PAN \& RB) Nomor 16 Tahun 2009 terkait Jabatan Fungsional Guru dan Angka Kredit untuk guru mata pelajaran dan guru kelas meliputi: (a) menyusun kurikulum pembelajaran pada satuan pendidikan; (b) menyusun silabus pembelajaran; (c) menyusun rencana pelaksanaan pembelajaran; (d) melaksanakan kegiatan pembelajaran; (e) menyusun alat ukur/soal sesuai mata pelajaran; (f) menilai dan mengevaluasi proses dan hasil belajar pada mata pelajaran yang diampu; (g) menganalisis hasil penilaian pembelajaran; (h) melaksanakan pembelajaran, perbaikan dan pengayaan dengan memanfaatkan hasil penilaian dan evaluasi; (i) menjadi pengawas penilaian dan evaluasi terhadap proses dan hasil belajar tingkat sekolah dan nasional; (j) membimbing guru pemula dalam program induksi; (k) membimbing siswa dalam kegiatan ekstrakurikuler proses pembelajaran; (l) melaksanakan pengembangan diri; (m) melaksanakan publikasi ilmiah dan; n) membuat karya inovatif. Kinerja guru menurut Castetter dalam Wahab dan Umiarso (2010) terdapat empat kriteria kinerja yaitu: (a) karakteristik individu, (b) proses, (c) hasil, dan (4) kombinasi antara karakter individu, proses dan hasil.

\subsubsection{Keefektifan Sekolah}

Tingkat keefektifan sekolah yang telah dicapai di SDN se Kecamatan Lawang, Kabupaten Malang ini tergolong dalam kategori sedang yang dilihat dari nilai mean variabel keefektifan sekolah sebesar 141.86, berada pada interval 150,86 - 163,72. Hal ini berarti rata-rata SDN di Kecamatan Lawang telah mencapai keefektifan sekolah sesuai dengan karakteristik keefektifan sekolah dalam penelitian ini. Kriteria keefektifan sekolah yang digunakan dalam penelitian ini yaitu pengembangan kurikulum, lingkungan belajar yang kondusif, ramah siswa, manajemen sekolah yang baik, berorientasi pada prestasi, dan keterlibatan orangtua dan masyarakat.

Butir-butir pernyataan dalam variabel keefektifan sekolah ini dikembangakan dan dimodifikasi dari hasil penelitian CCEF (California Center for Effective School) dalam Suparlan (2016), Danim (2006), dan Suharno (2008). Penelitian CCEF memaparkan enam pilar sekolah 
efektif, namun dalam penelitian Suparlan (2016) menggunakan enam pilar sekolah efektif dan ditambahkan dengan kurikulum dan manajemen sekolah. Kemudian menjabarkan pilar tersebut dengan indikator pilar yaitu (1) kepala sekolah yang profesional, (2) kurikulum yang luas dan berimbang, (3) lingkungan belajar yang kondusif, (4) ramah siswa, (5) manajemen sekolah, (6) penilaian dan pelaporan prestasi siswa, terdiri dari: (1) prestasi akademik; dan (2) prestasi non akademik, (3) pelibatan orangtua dan masyarakat yang tinggi.

Tujuan utama dari sekolah yaitu memberikan pelayanan yang terbaik kepada stakeholders (peserta didik, dan masyarakat) dalam memenuhi kebutuhan akan pendidikan di sekolah. Kepala sekolah, guru dan staf/pegawai berupaya sebaik mungkin dalam pemenuhan kebutuhan peserta didik terkait pembelajaran yang kondusif, berorientasi pada prestasi siswa dan sekolah, mengelola pembelajaran agar peserta didik mendapatkan Nilai Ujian Nasiona (NUN) yang tinggi, bahkan mengarahkan dan membantu peserta didik untuk dapat melanjutkan pendidikan ke jenjang yang lebih tinggi. Dikarenakan di Indonesia NUN peserta didik turut dijadikan sebagai salah satu tolok ukur keberhasilan pembelajaran peserta didik mulai dari jenjang pendidikan dasar dan pendidikan menengah. Bahkan peserta didik yang akan melanjutkan pendidikan ke jenjang yang lebih tinggi tidak dipungkiri bahwa NUN menjadi salah satu persyaratan. Untuk mencapai indikator keefektifan sekolah tersebut diperkuat dengan pendapat Suharno (2008: 186-188) yang memaparkan indikator keefektifan sekolah yang terdiri dari: (a) keterlibatan masyarakat, (b) berorientasi pada prestasi, (c) kepemimpinan pendidikan, (d) iklim yang nyaman, (e) kesempatan untuk belajar, (f) evaluasi hasil peserta didik.

Penelitian yang dilakukan Gaziel, (1998) dengan judul "School-Based Management as a Factor in School Effectiveness" menghasilkan bahwa sekolah efektif di Israel menghasilkan bahwa sekolah efektif dapat dirintis melalui kecenderungan otonomi yang lebih besar untuk sekolah sebagai gerakan nyata dalam pendidikan masa kini. Sekolah lebih diberi kekuasaan dalam pembuatan keputusan internal yang disetujui Menteri Pendidikan terkait dalam pembuatan keputusan, evaluasi sekolah, pengembangan staf dan kelembagaan, desain kurikulum dan lain-lain. Jadi untuk mencapai keefektifan sekolah, sekolah harus mampu membuat suatu perubahan sesuai dengan kondisi sekolah, serta juga adanya komitmen seluruh warga sekolah dalam mencapai tujuan sekolah yang telah ditetapkan. Keterlibatan dan komitmen seluruh sumber daya manusia di sekolah sangat menentukan keefektifan sekolah.

\subsubsection{Hubungan Kepemimpinan Visioner dan Keefektifan Sekolah}

Hasil perhitungan korelasi Pearson Product Moment untuk mengetahui hubungan kepemimpinan visioner $\left(\mathrm{X}_{1}\right)$ dan keefektifan sekolah $(\mathrm{Y})$ diperoleh hasil signifikansi sebesar $0,000<0,050$, maka hipotesis penelitian yaitu $\mathrm{H}_{0}$ ditolak dan $\mathrm{H}_{1}$ diterima. Artinya secara parsial terdapat hubungan signifikan antara kepemimpinan visioner dan keefektifan sekolah di SDN se-Kecamatan Lawang, Kabupaten Malang. Hasil penelitian ini menunjukan bahwa kepala sekolah di SDN Kecamatan Lawang, Kabupaten Malang telah memiliki dan menerapkan kepemimpinan visioner dalam mencapai keefektifan sekolah. Karena kepemimpinan secara dominan dan utama mempengaruhi kinerja suatu organisasi, dapat dikatakan bahwa sekolah yang bermutu dapat diwujudkan bagaimana kinerja dan komitmen utama dari pimpinan dalam merencanakannya (Komariah dan Triatna, 2004). Hal ini mendukung bahwa dengan adanya kepala sekolah yang visioner dalam arti kepala sekolah mampu dalam menciptakan, merumuskan, mentransformasikan, dan mengimplementasikan visi dan misi yang dimiliki ke 
dalam program/kegiatan yang ada di sekolah serta tentunya berorientasi pada kebutuhan di masa depan. Maka dengan kemampuan kepemimpinan visioner kepala sekolah tersebut dapat mencapai efektivitas sekolah yang telah ditentukan.

Hasil penelitian ini secara parsial terdapat hubungan yang signifikan antara kepemimpinan visioner dan keefektifan sekolah di SDN se Kecamatan Lawang, Kabupaten Malang. Perolehan kepemimpinan kepala sekolah dalam kategori sedang dapat menunjang pencapaian keefektifan sekolah dalam kategori sedang pula. Dalam hal ini berarti kepala sekolah telah mampu dalam menciptakan, merumuskan, mentransformasikan, dan mengimplementasikan visi dan misi ke dalam program/kegiatan yang ada di sekolah sehingga membangun komitmen bersama dalam mencapai keefektifan sekolah.

Penelitian ini diperkuat oleh penelitian Irwana, (2015) diperoleh hasil bahwa variabel kepemimpinan kepala sekolah memiliki pengaruh positif terhadap efektivitas sekolah sebesar $39,6 \%$ dan sisanya 46,4\% dipengaruhi oleh variabel lainnya. Hipotesis ini diperkuat melalui perolehan uji korelasi dengan nilai 0,396 sehingga diperoleh kesimpulan adanya hubungan yang signifikan antara kepemimpinan visioner kepala sekolah terhadap efektivitas sekolah dasar se-Kecamatan Astana Anyar Kota Bandung. Persamaan hasil penelitian ini dengan penelitian Irwana (2015) bahwa sama-sama menguji kepemimpinan visioner dengan keefektifan sekolah. Perbedaan penelitian ini dengan dua penelitian tersebut yaitu pada sub variabel dan indikator yang digunakan, lokasi penelitian, dan jumlah responden yang digunakan.

\subsubsection{Hubungan Kinerja Guru dan Keefektifan Sekolah}

Hasil penelitian ini memperoleh hasil signifikansi $0,000<0,050$, maka hipotesis penelitian yaitu $\mathrm{H}_{0}$ ditolak dan $\mathrm{H}_{1}$ diterima. Jadi secara parsial terdapat hubungan yang signifikan antara kinerja guru dan keefektifan sekolah di SDN se Kecamatan Lawang, Kabupaten Malang. Perolehan kinerja guru dalam kategori sedang dapat menunjang pencapaian keefektifan sekolah dalam kategori sedang pula. Dalam hal ini berarti guru telah dapat melaksanakan perannya dalam perencanaan pembelajaran, pelaksanaan pembelajaran, membimbing guru, membimbing siswa, serta melaksanakan pengembangan diri. Dengan guru yang mempunyai kinerja yang baik dalam proses pembelajaran di sekolah hal ini dapat menunjang dalam pencapaian keefektifan sekolah.

Dengan kinerja guru yang baik tersebut juga dapat mencapai kriteria sekolah efektif. Kriteria sekolah efektif yang digunakan dalam penelitian ini yaitu pengembangan kurikulum, lingkungan belajar yang kondusif, ramah siswa, manajemen sekolah yang baik, berorientasi pada prestasi, dan keterlibatan orangtua dan masyarakat. Dilihat dari kriteria keefektifan sekolah tersebut maka kinerja guru sangatlah menentukan ke ketercapaian keefektifan sekolah, karena sebagian besar proses belajar mengajar dan manajemen sekolah dilaksanakan secara langsung oleh guru dengan arahan dan bimbingan dari kepala sekolah. hal ini diperkuat oleh Wahab dan Umiarso (2010) bahwa sangat penting dalam melakukan pengukuran kinerja tenaga kerja sebagai barometer kesuksesan organisasi. Kinerja sumber daya manusia (SDM) menjadi fokus parameter kesuksesan organisasi dalam mencapai tujuan dan interpretasi eksistensi organisasi di masa depan.

Penelitian terdahulu oleh Irwana (2015) diperoleh hasil bahwa variabel kinerja guru memiliki pengaruh positif terhadap efektivitas sekolah sebesar $42,7 \%$ dan sisanya $46,4 \%$ 
dipengaruhi oleh variabel lainnya. Hipotesis ini diperkuat melalui perolehan uji korelasi dengan nilai 0,427 sehingga diperoleh kesimpulan adanya hubungan yang signifikan antara kinerja guru terhadap efektivitas sekolah dasar se Kecamatan Astana Anyar Kota Bandung. Hasil regresi diperoleh variabel kinerja guru ditemukan hasil uji t sebesar 2,379 dengan derajat kebebasan $\mathrm{n}-\mathrm{k}-1=34-2-1=31$, dan P-value $=0,024 \leq 0,050$. Hal ini menandakan Ha diterima yang berarti koefisien regresi variabel kinerja guru $\left(\mathrm{X}_{2}\right)$ terhadap efektivitas sekolah (Y) signifikan. ini mengandung arti bahwa variabel kinerja guru dapat mempengaruhi variabel efektivitas sekolah. Persamaan hasil penelitian ini dengan penelitian Irwana (2015) bahwa sama-sama menguji kinerja guru dengan keefektifan sekolah. Perbedaan penelitian ini dengan dua penelitian tersebut yaitu pada sub variabel dan indikator yang digunakan, lokasi penelitian, dan jumlah responden yang digunakan.

\subsubsection{Hubungan Kepemimpinan Visioner dan Kinerja Guru dengan Keefektifan Sekolah}

Hasil penelitian ini memperoleh hasil signifikansi 0,000 $<0,050$, maka menghasilkan hipotesis penelitian yaitu $\mathrm{H}_{0}$ ditolak dan $\mathrm{H}_{1}$ diterima. Artinya terdapat hubungan signifikan antara kepemimpinan visioner dan kinerja guru dengan keefektifan sekolah di SDN seKecamatan Lawang, Kabupaten Malang. Hasil ini juga ditunjang dengan perolehan kepemimpinan visioner kepala sekolah di SDN se Kecamatan Lawang, Kabupaten Malang dalam kategori sedang sehingga dapat dikatakan bahwa kepala sekolah telah melaksanakan dan menerapkan kepemimpinan visioner dengan baik sesuai dengan karakteristik yang digunakan dalam penelitian ini. Hal ini diperkuat dengan adanya konsep kepemimpinan visioner bahwa pemimpin yang visioner harus mampu menciptakan, merumuskan, mentransformasikan, dan mengimplementasikan visi dan misi yang dimiliki ke dalam program/kegiatan yang ada di sekolah serta tentunya berorientasi pada kebutuhan di masa depan Komariah dan Triatna, 2004). Dengan adanya kemampuan visioner kepala sekolah tersebut sehingga mampu mempengaruhi guru, dan peserta didik sehingga mampu mencapai tujuan yang ingin dicapai sekolah berdasarkan pada visi, misi dan komitmen bersama yang telah di buat.

Selain itu kinerja guru di SDN se Kecamatan Lawang, Kabupaten Malang juga dalam kategori sedang juga. Hal ini berarti guru-guru telah menerapkan dan melaksanakan kinerjanya dengan baik dan mempunyai komitmen yang tinggi dalam mencapai tujuan pendidikan di sekolah. karakteristik yang digunakan dalam penelitian ini meliputi perencanaan pembelajaran, pelaksanaan pembelajaran, membimbing guru, membimbing siswa, serta melaksanakan pengembangan diri. Dengan guru telah melaksanakan tugas dan kewajiban sesuai dengan standar kriteria kinerja tersebut maka dapat mencapai keefektifan pembelajaran peserta didik di sekolah.

Keefektifan sekolah di SDN se Kecamatan Lawang, Kabupaten Malang ini tergolong dalam kategori sedang. Hal ini berarti, kepala sekolah, guru, dan peserta didik yang ada di Kecamatan Lawang ini sudah berkomitmen untuk mencapai efektivitas sekolah. Efektivitas merupakan dimensi tujuan manajemen yang berfokus pada hasil, sasaran, dan target yang diharapkan (Komariah dan Triatna, 2004). Sehingga seluruh warga sekolah harus mempunyai tujuan dan komitmen yang sama untuk mencapai keefektifan sekolah sesuai yang telah direncanakan sebelumnya. Kriteria keefektifan sekolah yang digunakan dalam penelitian ini 
yaitu: pengembangan kurikulum, lingkungan belajar yang kondusif, ramah siswa, manajemen sekolah yang baik, berorientasi pada prestasi, dan keterlibatan orangtua dan masyarakat.

Hasil dari penelitian ini yaitu secara simultan terdapat hubungan yang signifikan antara kepemimpinan visioner dan kinerja guru dengan keefektifan sekolah. Kontribusi yang signifikan tentunya berasalan dengan adanya dua variabel bebas yaitu kepemimpinan visioner dalam kategori sedang dan kinerja guru dalam kategori sedang memberikan kontribusi untuk mencapai keefektifan sekolah dalam kategori sedang pula. Sehingga terdapat keseimbangan tingkat kategori antara tiga variabel tersebut. Jadi dalam penelitian ini kepemimpinan kepala sekolah telah memiliki dan menerapkan kepemimpinan visioner dalam proses pendidikan di sekolah. Dengan adanya pemahaman dan komitmen visi dan misi dapat menunjang kinerja guru yang lebih baik pula, sehingga dapat mencapai keefektifan sekolah.

Penelitian lain, Supardi (2014) diperoleh hasil bahwa terdapat pengaruh positif dan signifikan kepemimpinan visioner kepala raudhatul athfal dan budaya organisasi terhadap disiplin kerja guru. Pengaruh kepemimpinan visioner kepala raudhatul athfal terhadap disiplin kerja guru sebesar 40,13\%. Pengaruh budaya organisasi sekolah terhadap disiplin kerja guru sebesar 30,91\%. Pengaruh kepemimpinan visioner kepala raudhatul athfal terhadap budaya organisasi $12,67 \%$. Pengaruh kepemimpinan visioner kepala raudhatul athfal terhadap budaya organisasi sekolah sebesar 21,25\%. Pengaruh tersebut karena kepemimpinan visioner kepala RA berperan dalam menumbuhkan dalam diri guru untuk melaksanakan dan menegakkan disiplin kerja. Guru melaksanakan disiplin kerja dalam pekerjaan sebagai pendidik, pengajar dan pembimbing di kelas. Oleh karena itu kepemimpinan visioner kepala RA merupakan salah satu komponen penting dalam meningkatkan disiplin kerja guru.

Penelitian kedua, oleh Mappaenre (2014) memperoleh hasil bahwa secara simultan kepemimpinan visioner kepala sekolah dan kepemimpinan diri guru berkontribusi secara signifikan terhadap sekolah efektif. Kedua variabel bebas dalam penelitian ini yaitu kepemimpinan visioner kepala sekolah dan kepemimpinan diri guru dapat mempengaruhi peningkatan sekolah efektif. Kontribusi yang signifikan tersebut tentu sangat beralasan dengan kondisi kedua variabel bebas tersebut berada taraf kategori baik. Artinya kepala sekolah secara empiris telah berperan sebagai pemimpin visioner dalam menjalankan roda organisasi sekolahnya. Persamaan hasil penelitian ini dengan penelitian Supardi (2014) dan Mappaenre, (2014) bahwa sama-sama menguji kepemimpinan visioner dan 2 variabel lainnya. Perbedaan penelitian ini dengan dua penelitian tersebut yaitu pada jenis variabel, jumlah sub variabel, dan indikator yang digunakan, lokasi penelitian serta jumlah responden.

\section{Simpulan}

Simpulan penelitian ini yaitu (1) tingkat kepemimpinan visioner kepala sekolah menurut persepsi guru di SDN Kecamatan Lawang, Kabupaten Malang dalam kategori sedang; (2) tingkat kinerja guru di SDN Kecamatan Lawang, Kabupaten Malang dalam kategori sedang;

(3) tingkat keefektifan sekolah menurut persepsi guru di SDN Kecamatan Lawang, Kabupaten Malang dalam kategori sedang; (4) secara parsial terdapat hubungan signifikan antara kepemimpinan visioner dan keefektifan sekolah di SDN Kecamatan Lawang, Kabupaten Malang; (5) secara parsial terdapat hubungan signifikan antara kinerja guru dan keefektifan sekolah di SDN Kecamatan Lawang, Kabupaten Malang; (6) secara simultan terdapat hubungan signifikan antara kepemimpinan visioner dan kinerja guru dengan keefektifan sekolah di SDN Kecamatan Lawang, Kabupaten Malang. 


\section{Daftar Rujukan}

Gaziel, H. (1998). School-based management as a factor in school effectiveness. International Review of Education, 44(4), 319-333.

Irwana, A. (2015). Kepemimpinan Kepala Sekolah dan Kinerja Guru terhadap Efektifitas Sekolah di Sekolah Dasar Negeri. Jurnal Administrasi Pendidikan, 22 (2), (104-119).

Kantabutra, S. (2003). An empirical examination of relationships between customer and staff satisfaction in retail apparel stores in Sydney. (Online), (https:// link.springer.com).

Kantabutra, S. (2005). Improving Public School Performance through Vision-based Leadership: Asia Pacific Education Review, 6 (2), 124-136.

Kartanegara, D. (2013). Strategi Membangun Ekskutif. (Online), (http://www.duniamis.co.id), diakses pada 28 Desember 2017.

Komariah, A., \& Triatna, C. (2004). Visionary Leadership Menuju Sekolah Efektif. Jakarta: Bumi Aksara.

Peraturan Menteri Nomor 19 Tahun 2007 tentang Standar Pengelolaan Pendidikan Oleh Satuan Pendidikand Dasar dan Menengah. (Online),

Rakhmat, J. (2011). Psikologi Komunikasi. Bandung: Remaja Rosdakarya.

Suharno. (2008). Manajemen Pendidikan: Sebuah Pengantar bagi Para Calon Guru. Surakarta: LPP UNS dan UNS Press.

Supardi. (2014). Pengaruh Kepemimpinan Visioner Kepala Raudahtul Athfal Dan Budaya Organisasi Terhadap Disiplin Kerja Guru Raudahtul Athfal Kecamatan Ciledug Kota Tangerang, Jurnal Qathrunâ. 1 (1): 206220. Dari http://www.portalgaruda.org.

Umar, H. (2003). Metode Riset Perilaku Organisasi. Jakarta: Gramedia Pustaka Utama.

Undang-Undang Republik Indonesia Nomor 14 Tahun 2005 tentang Guru dan Dosen. (Online), (http://www.jdih.kemenkeu.go.id), diakses pada 10 Pebruari 2018.

Undang-Undang Sistem Pendidikan Nasional Nomor 20 Tahun 2003. Jogjakarta: Divapress.

Widyawati, F., A. (2015). Hubungan Kepemimpinan Visioner Kepala Sekolah Dan Tingkat Kinerja Tenaga Kependidikan Dengan Kualitas Sekolah Di Smpn Se-Kota Malang. (Online), (httpp://www.ap.fip.um.ac.id), diakses pada 10 Januari 2018. 